\title{
PROJETOS HIDRELÉTRICOS EM TERRITÓRIOS INDÍGENAS NO SUL DO BRASIL NO CONTEXTO DA DITADURA CIVIL- MILITAR: UMA ANÁLISE A PARTIR DO ACERVO DE SILVIO COELHO DOS SANTOS
}

ELIS DO NASCIMENTO SILVA ${ }^{1}$

UFSC

\begin{abstract}
RESUMO: Este artigo tem como objetivo publicizar alguns dos documentos do acervo do antropólogo Silvio Coelho dos Santos que revelam contextos de violação de direitos humanos dos povos indígenas no Sul do Brasil nos processos de implantação de projetos hidrelétricos em seus territórios tradicionais, durante a ditadura civil-militar instaurada no país. De forma especial, tem como foco abordar os estudos antropológicos produzidos durante este período por Silvio Coelho dos Santos e equipe no âmbito do Projeto Uruguai, concebido pela Eletrosul nos anos 1960 para a exploração integral do potencial energético da bacia do rio Uruguai (SC/RS), prevendo a implantação de cerca de 22 aproveitamentos hidrelétricos em seu trecho nacional. Os locais selecionados para a implantação desse conjunto de hidrelétricas na bacia do rio Uruguai correspondem aos territórios tradicionalmente ocupados pelas populações indígenas Kaingang e Guarani, constituindo uma ameaça à vida, às territorialidades e aos direitos desses povos. Este artigo visa, portanto, analisar a conjuntura de concepção deste projeto e o contexto de realização destes estudos, buscando refletir acerca de seus efeitos e articulações com os povos indígenas desta região latino-americana.
\end{abstract}

PALAVRAS-CHAVE: povos indígenas; hidrelétricas; Projeto Uruguai.

ABSTRACT: This article aims to publicize some of the documents of the collection by the anthropologist Silvio Coelho dos Santos that reveal contexts of human rights violations of Indigenous peoples in the South of Brazil in the processes of implementation of hydroelectric projects in their traditional territories during the civil-military dictatorship established in the country. In particular, it focuses on the anthropological studies produced during this period by Silvio Coelho dos Santos and team within the scope of the Uruguay Project, designed by Eletrosul in the 1960s to fully exploit the energy potential of the Uruguay River basin (SC/RS), providing for the implementation of about 22 hydroelectric projects in its national stretch. The sites selected for the implementation of this set of hydroelectric dams in the Uruguay River basin correspond to the territories traditionally occupied by the Kaingang and Guarani Indigenous populations, constituting a threat to the lives, territorialities and rights of these peoples. This article therefore aims to analyze the conceptual framework of this project and the context of these studies, seeking to reflect on its effects and articulations with the Indigenous peoples of this Latin American region.

\footnotetext{
${ }^{1}$ Bacharela em Ciências Sociais (UFSC) e mestra em Antropologia Social pelo Programa de Pós-Graduação em Antropologia Social da Universidade Federal de Santa Catarina (PPGAS/UFSC). Atualmente é doutoranda no PPGAS/UFSC e pesquisadora do Núcleo de Estudos de Populações Indígenas (NEPI/Dep. de Antropologia/UFSC). E-mail: elis.naser@gmail.com .
} 


\section{Apresentação}

Durante a realização de minha pesquisa de mestrado no Programa de Pós-Graduação em Antropologia Social (PPGAS) da Universidade Federal de Santa Catarina (UFSC), entre os anos 2014 e 2016, tive a oportunidade de conhecer e analisar o acervo do antropólogo e professor Silvio Coelho dos Santos, sobretudo a parte situada no Núcleo de Estudos de Povos Indígenas (NEPI), fundado por ele com o intuito de desenvolver pesquisas na área da etnologia indígena e promover diálogos com/relacionados a estas populações - de forma especial, as que ocupam territórios no Sul do Brasil.

Embora minha dissertação tivesse como foco a abordagem das relações estabelecidas entre a antropologia, os projetos hidrelétricos e os povos indígenas no Sul do Brasil (SILVA, 2016), principalmente entre os anos 1970 e 1990, foi inevitável durante esta pesquisa no acervo de Silvio Coelho dos Santos o contato com importantes documentos, correspondências, gravações, registros audiovisuais, entre outros materiais relacionados aos diversos contextos e percursos históricos dos povos indígenas do Sul, das demais regiões do país e, também, dos demais países da América Latina.

Pretendo, neste artigo, trazer ao conhecimento alguns dos documentos situados no acervo de Silvio Coelho dos Santos que considero relevantes para a compreensão dos contextos de violação dos direitos humanos dos povos indígenas durante o regime de ditadura civilmilitar no Brasil a partir de alguns dos projetos hidrelétricos propostos pelos governos a serem implantados em territórios indígenas no Sul do país.

Para o entendimento do que consiste e reúne este acervo, faz-se necessária uma breve apresentação de seu "dono", o antropólogo e professor Silvio Coelho dos Santos, sendo um desafio relatar sua extensa trajetória acadêmica e caminhos de atuação junto aos povos indígenas do 
Sul do país, vistos os diferentes campos de estudo a que se dedicou ao longo de sua vida.

Nascido em Florianópolis (SC) em 7 de julho de 1938, Silvio Coelho dos Santos foi um dos primeiros antropólogos do Sul do país, onde inaugurou a etnologia indígena dos povos originários da região (ILHA, 2009; SILVA, 2015). Foi um dos fundadores do Programa de PósGraduação de Antropologia Social da UFSC (1979), presidente da Associação Brasileira de Antropologia (ABA) (1992-1994), professor emérito da UFSC, além de outros cargos e títulos que recebeu em reconhecimento à produção antropológica por ele desenvolvida dentro e fora do campus acadêmico. Graduado em História (1960), participou da terceira turma do Curso de Especialização em Antropologia Social, em 1962, ministrado pelo antropólogo Roberto Cardoso de Oliveira no Museu Nacional da UFRJ. Defendeu seu doutoramento em Antropologia na Universidade de São Paulo em 1972, com a tese Índios e brancos no sul do Brasil - a dramática experiência dos Xokleng, inicialmente sob orientação do antropólogo catarinense Egon Schaden e, posteriormente, por João Baptista Borges Pereira. Sua tese foi publicada em 1973 e reeditada em 1987, consistindo em uma de suas obras de referência para a etnologia indígena do Sul do país.

Antes dessa publicação, pelo caráter denunciatório de seus trabalhos no que tange às práticas genocidas e etnocidas dos órgãos indigenistas oficiais (SPI e Funai) para com os povos indígenas no sul do país, o seu livro $A$ integração do índio na sociedade regional: a função dos postos indígenas em Santa Catarina (SANTOS, 1970) foi apreendido pela censura do governo militar no ano de 1969, quando esse se encontrava em fase final de edição.

Silvio Coelho dos Santos também teve uma reconhecida atuação nos contextos de implantação de barragens e hidrelétricas em territórios indígenas no sul do Brasil desde o início dos anos 1970, quando ainda não era exigida a realização dos Estudos de Impacto Ambiental (EIA) e Relatórios de Impacto Ambiental (RIMA) para avaliação e licenciamento de obras causadoras de impactos sobre o meio ambiente, muito menos sobre a vida das populações afetadas. O prof. Silvio foi um dos precursores na antropologia brasileira a realizar estudos sobre projetos hidrelétricos e suas consequências para as populações indígenas no 
Brasil. Esse pioneirismo consagrado à pesquisa etnográfica foi iniciado no ano de 1967, juntamente com o pesquisador Paul Aspelin (ASPELIN; SANTOS, 1981), cujos resultados foram publicados em 1981 no livro Áreas Indígenas Ameaçadas por Projetos Hidrelétricos no Brasil2.

No caso específico da região Sul do Brasil, Silvio Coelho dos Santos assinalou em seus estudos a dominação de caráter colonial referente à práxis indigenista frente às políticas econômicas de desenvolvimento do Estado brasileiro, e fazia também das pesquisas e textos que publicava instrumento para denunciar as condições extremas de genocídio e etnocídio às quais os povos indígenas vinham sendo submetidos - como as situações dos povos Xokleng/Laklãnõ, Kaingang e Guarani, na década de 1960 (SANTOS, 1963, 1970, 1978, 1979, 1987).

Após seu falecimento em outubro de 2008 , grande parte de toda produção e material reunido por Silvio Coelho dos Santos (SCS) encontrase depositada e organizada no NEPI, no Museu de Arqueologia e Etnologia/UFSC Professor Oswaldo Rodrigues Cabral (MArquE), bem como uma parte sob salvaguarda da família de SCS. Com o objetivo de organizar, sistematizar e disponibilizar através do meio digital este material constitutivo do acervo de SCS, foi criado o Projeto Acervo Virtual Sílvio Coelho dos Santos ${ }^{3}$, de modo a viabilizar a devolução e o compartilhamento dos materiais de pesquisa às populações indígenas junto às quais o antropólogo atuou. Nesse conjunto encontram-se materiais de pesquisa relativos aos principais eixos de pesquisa aos quais SCS se dedicou durante sua trajetória4: a etnologia indígena; os grandes projetos de desenvolvimento e efeitos socioambientais sobre as populações locais; a antropologia e o direito; e, a mais recente de sua carreira, relativa à memória e história, tanto da antropologia quanto do setor elétrico no Sul do Brasil (SILVA, 2015).

Podem ser encontrados no acervo materiais relacionados ao direito ambiental e direitos humanos, nos âmbitos nacional e internacional, bem como é facilitado o acesso às produções acadêmicas e trabalhos técnicos

\footnotetext{
${ }^{2}$ Para a antropóloga Catullo (1996, p. 11), esta obra consiste em "um dos trabalhos mais importantes na literatura de 'impactos' de Projetos de Grande Escala”.

${ }^{3}$ Para informações e esclarecimentos mais detalhados acerca do Projeto AVISC, ver Fürbringer (2013); Silva (2015) e o próprio site do projeto: 〈https://avisc.wordpress.com/about/ $>$.

${ }^{4}$ Para conhecimento de toda a bibliografia e temas abordados nos trabalhos de Silvio Coelho dos Santos, veja-se Ilha - Revista de Antropologia (2009) e Silva (2015).
} 
realizados sobre casos específicos (a exemplo, laudos, relatórios e perícias) durante o tempo de atividade do antropólogo. Especificamente, pude perceber que esta parte do NEPI reúne, principalmente, um extenso material sobre a implantação de hidrelétricas e suas consequências sociais no Brasil e demais países da América Latina, a exemplo da Argentina, Paraguai, México, bem como de outros países do mundo, como Canadá, Índia e outros. Nesse levantamento, pude identificar também um conjunto de pesquisadores que nos anos 1970 e 1980 dedicaram-se a esta temática, do qual o prof. Silvio fazia parte e mantinha contatos com alguns deles, evidenciando-se a existência de uma problemática que afetava (e ainda afeta) diversos contextos em que ocorreu a implantação de projetos de desenvolvimento na América Latina, bem como uma forma convergente de atuação desses pesquisadores.

\section{Contextualizando: a política energética, os estudos e processos de licenciamento no Brasil durante o "milagre econômico"}

A política nacional de geração de energia hidroelétrica em larga escala que se inaugura na década de 1960, e se consolida nos anos 1970, priorizou a região Sul para implantação de projetos hidrelétricos planejados pelo Estado, através da subsidiária Eletrosul, integrando a proposta de ampliação do parque gerador para atender ao chamado "milagre econômico brasileiro" (1968-1974), que estava sendo impulsionado pelas políticas desenvolvimentistas dos governos ditatoriais militares (REIS, 1991, p. 190). Contudo, os vários projetos hidrelétricos planejados pelo Estado brasileiro para serem implantados no país a partir dos anos 1970 consistiram em sucessivos avanços sobre os territórios indígenas. São oportunas as observações de Santos e Aspelin (1982) sobre este contexto referente ao trato do Estado brasileiro com os povos indígenas naquele período de expansão econômica:

Dada a marcha acelerada do desenvolvimento econômico brasileiro e ao rápido crescimento na demanda por energia hidrelétrica, em face da expansão econômica nacional, o governo do Brasil pouco tem concretizado visando assegurar aos índios suas terras e 
culturas (Davis, 1978; Ribeiro, 1957) (SANTOS; ASPELIN, 1982, p. 7).

De acordo com o amplo e pioneiro estudo realizado por Aspelin e Santos (1982), diversos povos indígenas do Brasil foram atingidos e/ou ameaçados pelos empreendimentos hidroelétricos projetados pelos governos militares em 32 áreas indígenas ${ }^{5}$ naquele período por várias partes do país. As UHEs Tucuruí (PA), Balbina (AM) e Itaipu (PR) foram os primeiros aproveitamentos hidrelétricos de grande porte a afetarem as populações indígenas no país, cuja construção dos reservatórios provocou o alagamento das terras indígenas e o reassentamento compulsório de seus povos, gerando graves consequências para os seus modos de vida e domínio territoriais, afetando a sua sobrevivência física e reprodução cultural.

As ameaças de implantação de obras hidrelétricas sobre os territórios indígenas no país, especificamente no período que antecede a obrigatoriedade dos estudos para avaliação e licenciamento pelos órgãos responsáveis, foram também identificadas pelos levantamentos realizados durante os anos de 1984 e 1985 por equipes do programa Povos Indígenas no Brasil, do CEDI (Centro Ecumênico de Documentação e Informação), e do projeto Estudo sobre Terras Indígenas no Brasil: invasões, uso do solo, recursos naturais, do Museu Nacional (UFRJ). Publicado em novembro de 1987, este estudo constatou que:

Os planejamentos energéticos frequentemente têm ignorado a existência de grupos indígenas em áreas onde estão programadas a construção de hidrelétricas e barragens, ou a passagem de linhas de transmissão. Existem hidrelétricas em construção que afetam 8 áreas indígenas, enquanto outras 4 já sofreram redução de sua área ou deslocamento de comunidades. As unidades energéticas existentes $\mathrm{e}$ as constantes em planejamentos governamentais afetam um total de 40 áreas indígenas, que por sua vez representam em termos de extensão quase $40 \%$ (ou mais exatamente $39,28 \%$ do universo total) das terras indígenas (CEDI/PETI/MNRJ, 1987, p. 16).

\footnotetext{
${ }^{5}$ Segundo os autores, estes grandes projetos estavam situados na bacia do Rio Uruguai; no Rio Itajaí; no Rio São Francisco (represa de Itaparica); no Rio Tocantins (represa Tucuruí); no Rio Uatama (represa Balbina); na bacia do Rio Xingu e no Rio Paraná (Itaipú Binacional - Paraguai/Brasil).
} 
$\mathrm{Na}$ região Sul, entre as situações de ameaças aos territórios indígenas destacam-se os casos da construção da Usina Hidrelétrica Xanxerê, no Rio Chapecozinho, iniciada em 1965; da Usina Hidrelétrica de Salto Santiago, no Rio Iguaçu, iniciada em 1972 (HELM, 1996) e da Usina Hidrelétrica Binacional de Itaipu, no Rio Paraná, iniciada em 1975 (CARVALHO, 1981; SANTOS, 1994; NACKE; WEBER, 1996); além daquelas que compunham o denominado Projeto Uruguai para o aproveitamento integral da bacia do Rio Uruguai, abarcando os três estados do Sul do país (RS, SC e PR), o que será detalhado mais adiante. Embora não constitua um empreendimento para o aproveitamento hidrelétrico, a Barragem Norte, construída em 1976 para contenção de cheias na região do médio Vale do Itajaí (SC), consistiu em uma obra com graves consequências aos povos indígenas Xokleng/Laklãnõ, Kaingang e Guarani da TI Ibirama Laklãnõ (SANTOS, 1978; 1991; 1997).

Essas e outras denúncias já se faziam ouvir desde a década de 1960, quando a política indigenista brasileira foi alvo da atenção internacional, sobretudo através da publicação do Relatório Figueiredo, no qual foram constatadas e divulgadas internacionalmente inúmeras violações dos direitos humanos das populações indígenas do país, em virtude das investigações da Comissão Figueiredo (presidida pelo procurador Jader de Figueiredo Correa) para averiguação das acusações de esbulho e massacre contra os povos indígenas pelos funcionários do então Serviço de Proteção aos Índios (SPI). Naquele momento, a situação dos povos indígenas no Brasil foi exposta no cenário internacional, gerando uma onda de protestos no mundo inteiro que pressionou seus governos a intervirem junto às agências multilaterais mundiais, como o Banco Mundial e o BID.

Essas pressões a nível internacional geraram grandes entraves para os governos militares, que tiveram que tomar medidas emergenciais em relação à política indigenista brasileira e à proteção dos povos indígenas. Entre as medidas, destaca-se a extinção do SPI e a criação da Fundação Nacional do Índio (Funai). Como ressaltaram Davis e Menget:

Em 1967, após a avalanche internacional de críticas, o governo brasileiro extinguiu o velho Serviço de Proteção aos Índios que contava já com meio século e criou em 
seu lugar uma nova entidade conhecida como Fundação Nacional do Índio (Funai) (1981, p. 40-41).

Contudo, a mudança no órgão indigenista não assegurou proteção ou defesa dos direitos indígenas, que continuavam sofrendo sucessivas violências e perdas territoriais decorrentes das políticas de desenvolvimento implantadas pelos governos militares. Foi nessa mesma direção que Shelton Davis (1978), antropólogo norte-americano, denunciou em seu livro Vítimas do Milagre, que nos anos 1970 o Brasil fornecia "um dos mais claros exemplos modernos de um país onde os direitos das comunidades indígenas foram sacrificados em nome dos interesses maiores do desenvolvimento nacional" (p. 12). Destaca-se, ainda, a realização do Tribunal Bertand Russel (atualmente, Tribunal dos Povos) em 1980, momento em que o Brasil foi condenado internacionalmente por práticas de genocídio contra os povos indígenas ${ }^{6}$.

Apesar dessas mudanças no órgão indigenista oficial, o setor energético brasileiro concebia (assim como tem concebido até hoje) as populações indígenas como um entrave ao modelo de crescimento econômico, à medida que os recursos naturais ambicionados para a implantação de projetos hidrelétricos encontravam-se localizados, em sua maioria, junto aos territórios tradicionalmente ocupados por elas, a exemplo do caso da UHE Belo Monte. O discurso oficial da Eletrobrás sobre os povos indígenas, na década de 1980, era explícito em afirmar que: "A presença de comunidades indígenas representa um dos problemas ambientais de maior complexidade, no planejamento $e$ implementação de usinas hidrelétricas e linhas de transmissão" (ELETROBRÁS, 1986 apud CASTRO; ANDRADE, 1988, p. 7). Ou seja, os indígenas não eram somente considerados problema, mas também um "problema ambiental"7.

Foi neste cenário que a exigência de critérios e reorientações dos organismos internacionais de financiamento de projetos de desenvolvimento passaram a determinar a realização de estudos técnico-

\footnotetext{
6 Para maiores esclarecimentos sobre todo este contexto, ver: RELATÓRIO DA COMISSÃO FIGUEIREDO, 1968; CNBB, 1973; AEPPA, 1974; COMISSÃO DA VERDADE DO ESTDO DE SÃO PAULO, 2015.

${ }^{7}$ Como se verá adiante, o prof. Silvio Coelho dos Santos foi extremamente crítico ao tratar das questões sociais decorrentes da implantação de projetos hidrelétricos como 'problema ambiental', e foi atuante em demonstrar a inadequação desse tipo de noção (SANTOS, 2007). Para mais esclarecimentos sobre este assunto, ver Santos, Andrade (1988) e Leite (2005).
} 
científicos sobre os aspectos sociais e ambientais relacionados às grandes obras de desenvolvimento, como o caso particular dos projetos hidrelétricos no país. Assim,

a partir da década de 1970, começam a ser elaborados estudos sobre consequências ambientais da implantação de usinas hidrelétricas a fim de atender às solicitações dos agentes financeiros (Banco Interamericano de Desenvolvimento - BID e Banco Mundial - BIRD). O BID e o BIRD, após a Conferência de Estocolmo (ONU) sobre meio-ambiente e em resposta às pressões dos movimentos ecológicos, passaram a exigir estudos ambientais (VIANNA, 1989, p. 10).

Sendo obrigado a atender às pressões e exigências dos organismos internacionais de financiamento aos projetos de desenvolvimento, oficializadas através de diversas Declarações e Convenções, o Brasil teve que assumir posições cada vez mais favoráveis à preservação ambiental e à responsabilidade social (LEME MACHADO, 2013; LAGO, 2006). Esta posição foi condicionante no planejamento do setor elétrico brasileiro, podendo ser observado nas subsequentes ações estratégicas da Eletrobrás que, em 1986, editou o Manual de Estudos de Efeitos Ambientais dos Sistemas Elétricos, o estabelecimento de um Plano Diretor de Meio Ambiente (PDMA) e, ainda no mesmo ano, a criação do Comitê Consultivo de Meio Ambiente (CCMA), "integrado por profissionais de diversas áreas de conhecimento e independentes do setor elétrico" (SANTOS, 2007, p. 87).

Convém destacar que a obrigação legal de realizar estudos de impacto ambiental para obras dessa natureza surgiu apenas em 1986, com a regulamentação do licenciamento ambiental, prevista já na Lei da Política Nacional do Meio Ambiente de 1981 (CANALI, 2002). Até os anos 1980, o único critério de avaliação dos possíveis efeitos referentes aos projetos hidrelétricos consistia na regulamentação instituída pela legislação ambiental brasileira, promulgada na década de 1930 juntamente com o Código das Águas (Decreto 24.643, de 1934) para o estabelecimento do regime jurídico das águas no Brasil. Em 19818,

\footnotetext{
${ }^{8}$ Reflexo das pressões e acordos da conjuntura internacional, o Brasil buscou ajustar-se à agenda política ambiental mundial sem, no entanto, renunciar às prioridades econômicas estabelecidas pelo planejamento estatal em desenvolvimento, como as metas de produção de energia elétrica a serem atingidas. Assim, na década de 1980, instituiu-se no país a Política Nacional do Meio Ambiente (PNMA), pela Lei 6.938, de
} 
através da Lei 6.938, definiu-se a Política Nacional de Meio Ambiente, sendo criado posteriormente, através da Resolução 001 /86, o Conselho Nacional do Meio Ambiente (Conama), que dispõe sobre critérios básicos e diretrizes gerais para avaliação de impacto ambiental. A partir desta resolução, tornaram-se obrigatórios os Estudos de Impacto Ambiental (EIA) e o Relatório de Impacto no Meio Ambiente (RIMA) para avaliação de impactos e licenciamento de obras causadoras de efeitos socioambientais, entre as quais as usinas hidrelétricas.

Além de constituírem uma exigência dos organismos internacionais de financiamento de projetos de desenvolvimento no país, como as obras hidrelétricas, os estudos técnico-científicos também corresponderam ao planejamento estratégico dos governos militares no que se refere ao levantamento e mapeamento dos recursos naturais no território nacional. Deste modo, o projeto dos governos militares em promover 0 crescimento econômico acelerado a partir da década de 1970 passa a se consolidar mediante o financiamento e investimento do Estado brasileiro em estudos técnico-científicos nas mais diversas áreas, expertises e metodologias. Este caráter cientificista atrelado aos projetos de desenvolvimento naquele período pode ser percebido tanto na Amazônia, como demonstraram Becker (1992) ou loris (2014), quanto no Sul do país, como foi o caso dos estudos elaborados para a concepção e implantação do Projeto Uruguai a ser abordado a seguir, que se pautou por uma perspectiva científica multidisciplinar.

\section{O Projeto Uruguai e os estudos antropológicos sobre os efeitos das hidrelétricas às populações indígenas no Sul do Brasil nas décadas de 1970 e 1980}

No ano de 2015, realizei um levantamento minucioso do material contido no acervo do prof. Silvio Coelho dos Santos que está localizado no Núcleo de Estudos de Povos Indígenas (NEPI), de forma particular nos arquivos relacionados ao campo das barragens e hidrelétricas, grande parte pertencente ao Projeto Barragens - UFSC/CNPq. Foram realizados 
levantamentos do material relacionado com a linha de pesquisa sobre Barragens, Hidrelétricas e Povos Indígenas no NEPI. Nesse trabalho, fui mapeando livros, relatórios, autores, redes de pesquisadores, estudos de caso, etc., sobre a temática, e buscando apreender e dimensionar a esfera de atuação do antropólogo.

\section{Mapa - Hidrelétricas inventariadas pela Eletrosul no Projeto Uruguai}

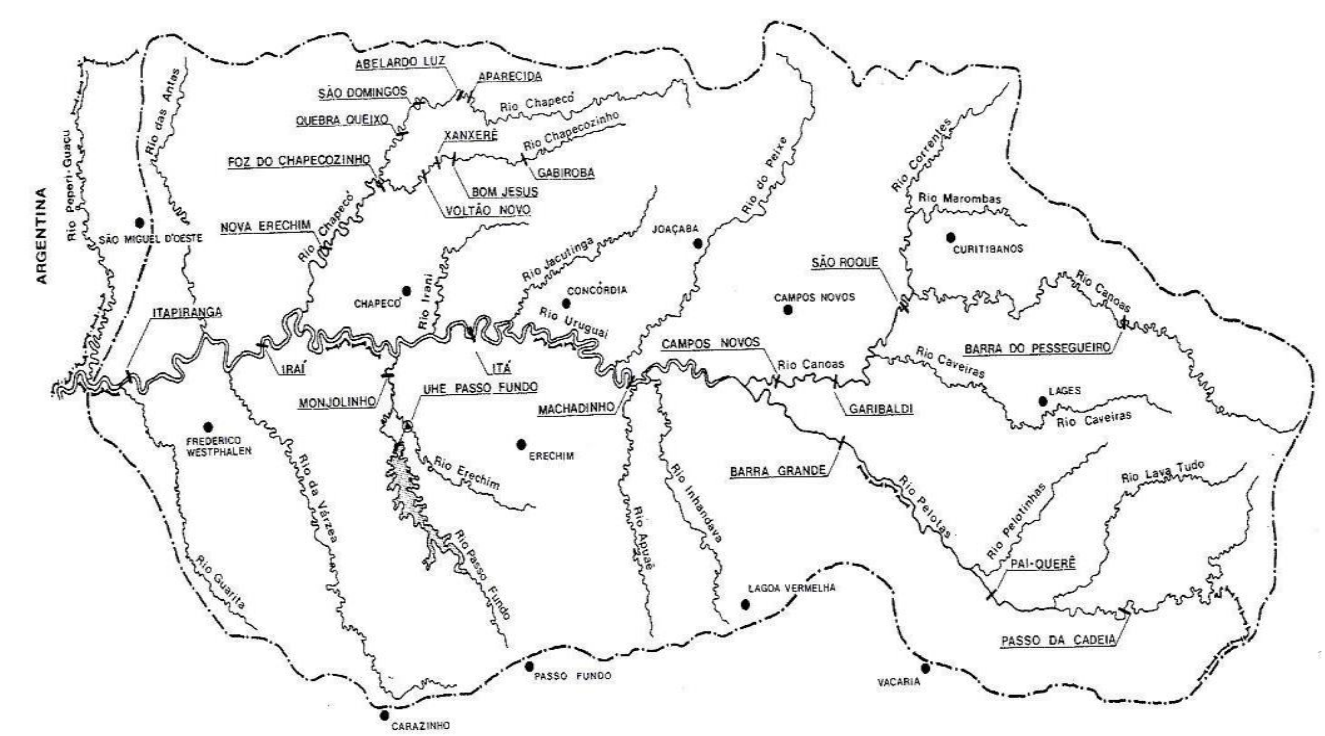

Fonte: Bacia Hidrográfica do Rio Uruguai - Estudo de Inventário Hidroenergético (ELETROSUL/CNEC, 1979).

Nessas "escavações" em seu acervo, notei que uma das estantes contém mais de dez caixas etiquetadas que correspondem, de forma geral, ao Projeto Uruguai, elaborado para o aproveitamento do potencial hidrelétrico da bacia do Rio Uruguai (estados do RS/SC), pelas Centrais Elétricas do Sul do Brasil S.A (Eletrosul), em 1977, sob o comando do Ministério das Minas e Energia. Em sua proposta original elaborada em 1969 pelo Consórcio Canadense-Americano-Brasileiro (CANAMBRA), o Projeto Uruguai apresentou quarenta possíveis localizações de barragens no Rio Uruguai (na parte brasileira) e nos seus afluentes: Chapecó e Chapecozinho; Inhandava ou Forquilha; Pelotas; Canoas e Caveiras, identificados de oeste para leste. Posteriormente, essas quarenta barragens propostas foram divididas sistematicamente em sete 
"alternativas" (ou conjuntos) mutuamente excludentes - as quais apresentavam uma pequena diferença relativa ao número de barragens a serem construídas, entre 22 e 27 (ASPELIN; SANTOS, 1982, p. 8). Após a escolha de uma das "alternativas" do projeto, configurou-se a implantação de 22 grandes usinas hidrelétricas ao longo desta bacia (ELETROSUL/CNEC, 1979), oito das quais já foram instaladas e estão em pleno funcionamento ${ }^{10}$.

Os relatórios e outros documentos relacionados ao caso do Projeto Uruguai que encontrei no acervo no NEPI possibilitaram observar um grande conjunto de trabalhos e pesquisas do prof. Silvio Coelho dos Santos e de uma equipe de alunos e pesquisadores, realizados ao longo dos anos 1970 junto a diversos contextos de terras indígenas que sofreram efeitos da implantação de usinas hidrelétricas na região Sul do país. Esses estudos demonstraram os diversos contextos de envolvimento de profissionais antropólogos e antropólogas, tanto pelas suas pesquisas, quanto pela elaboração de programas mitigadores de impactos, ou ainda na atuação política de assessoria aos indígenas na defesa de direitos.

De forma específica, o Projeto Uruguai apresentou certa dose de ineditismo no que se refere ao planejamento do setor elétrico no Brasil, o qual lhe é atribuído por dois fatores principais. Inicialmente, por consistir na primeira iniciativa do Estado brasileiro para a realização de levantamentos sistemáticos dos potenciais recursos energéticos de uma bacia hidrográfica, os quais foram desenvolvidos, entre os anos de 1966 e 1969, pelo CANAMBRA, na bacia do Rio Uruguai. Esses estudos visavam subsidiar o planejamento do aproveitamento e implantação de usinas hidroelétricas em longo prazo. Em segundo lugar, desses levantamentos resultou a primeira proposta governamental no Brasil para 0 aproveitamento integral do potencial energético de toda uma bacia hidrográfica. Essa ideia de aproveitamento integral do potencial energético de uma bacia se consolidou posteriormente com a condução de novos estudos pela Eletrosul, realizados a partir de 1977.

Estes estudos, inovadores à época do ponto de vista do planejamento energético estratégico, fizeram com que a Eletrosul

\footnotetext{
${ }^{10}$ Atualmente, a bacia do Rio Uruguai possui oito grandes usinas hidrelétricas em operação, sendo elas: Passo Fundo, Itá, Machadinho, Quebra-Queixo, Barra Grande, Campos Novos e Foz do Chapecó e Garibaldi. Ver: <http://apublica.org/2013/10/nem-tao-limpa-nem-tao-barata/>. Acesso em 30 maio 2018.
} 
constatasse uma série de fatores modificadores da paisagem ambiental e social que ocorreriam em decorrência da construção das hidrelétricas, assim como os possíveis efeitos que seriam originados com a implantação das obras hidrelétricas, determinando, assim, a necessidade de realização de estudos de avaliação socioeconômicos e físico-territoriais, que deveriam ser conduzidos a partir de uma equipe multidisciplinar.

Com essa constatação, o grupo técnico da Eletrosul convidou o antropólogo Silvio Coelho dos Santos para coordenar, conjuntamente a uma equipe de pesquisadores do Programa de Pós-Graduação em Ciências Sociais da UFSC (PPGCS/UFSC), a realização de estudos e levantamentos, efetivados através de duas consultorias. Estas consultorias, realizadas nos anos de 197811 e 198012, tinham como escopo a identificação das áreas indígenas atingidas pela implantação deste projeto hidrelétrico na bacia do Rio Uruguai, nos estados de Santa Catarina e Rio Grande do Sul13, como também a definição de medidas mitigadoras para os indígenas que teriam suas terras afetadas pelo empreendimento.

Os estudos realizados, entre 1978 e 1980, pela equipe de antropólogos do Programa de Pós-Graduação em Ciências Sociais da UFSC, sob coordenação do prof. Silvio Coelho dos Santos, identificaram e apontaram uma série de efeitos e consequências deletérias aos povos indígenas Kaingang e Guarani e seus territórios, que resultariam da implantação das hidroelétricas previstas no Projeto Uruguai. Entre as diversas consequências "diretas" e "indiretas", como eram denominadas, a equipe demonstrou as terras que seriam alagadas - casas, escolas, estradas, sedes dos postos, entre outras, teriam que ser relocadas -, bem como prejuízos de difícil previsão, como efeitos psicológicos, desorganização social, etc. (SANTOS, 1991, p. 51). Quando se referem especificamente à Terra Indígena Xapecó - como veremos adiante, a mais afetada entre todas pelo Projeto Uruguai (cerca de dez barragens

\footnotetext{
11 UFSC/FAPEU/ELETROSUL. Projeto Uruguai: os barramentos e os índios. Relatório de Pesquisa. Florianópolis, 1978.

12 Esta segunda consultoria foi realizada especificamente na TI Ligeiro, tendo como referência: UFSC/FAPEU/ELETROSUL. Projeto Uruguai: consequências da construção da Barragem Machadinho para os índios do P.I Ligeiro (RS). Florianópolis, 1980.

${ }^{13}$ Para maiores esclarecimentos, ver: Aspelin e Santos (1982) e UFSC/FAPEU/ELETROSUL (1980).
} 
previstas somente nessa $\mathrm{TI}$ ), os antropólogos esclarecem em seus relatórios que a implantação destas hidrelétricas consistiria em

um desastre de proporções incríveis, porque esta população, em comparação com a população nãoindígena também adversamente afetada, não tem para onde ir. Não falam o português; as outras reservas indígenas já são minifúndios efetivos e o seu crescimento demográfico normalmente até o ano da implantação destas barragens já vai tornar sua área pequena, sem falar em sofrer inundações como as aqui estudadas (UFSC/FAPEU/ELETROSUL, 1978, p. 90).

O trabalho de campo foi realizado durante oito dias, quando os pesquisadores foram surpreendidos pelo acompanhamento de militares, que surgiram sem que eles fossem informados previamente. O Relatório informa que:

Imediatamente ao chegar a autorização da FUNAI, a equipe se deslocou para o campo. Durante a viagem Florianópolis-Sananduva, via Concórdia e Marcelino Ramos (RS), aproveitou-se para conhecer toda a área de influência da barragem Machadinho. Chegando a Sananduva, no segundo dia de viagem, imediatamente procurou-se atingir a sede do P.I Ligeiro. [...] Algumas situações não previstas logo se fizeram sentir. Em primeiro lugar o Cacique [Leonídio Braga] deixou claro que os indígenas estavam esperando a equipe e que tinham ciência, tanto da tarefa, como dos prejuízos iminentes a que estavam sujeitos. E por isso desejavam acertar uma forma justa de obter indenizações, as quais seriam definitivas por toda a comunidade indígena. Isto implicava numa reunião com o Conselho, para que se discutisse a situação da reserva perante a construção da barragem Machadinho. [...] Em segundo lugar, a equipe, ao chegar, encontrou militares do Exército Nacional junto à sede do P.I. Feitas as apresentações, tomou-se conhecimento que o grupo era sediado em Passo Fundo (RS) e que se encontrava na área efetuando investigações de rotina entre os indígenas. Contudo, não se deixou de ficar surpreso quando os militares se acomodaram para participar, sem interferir, do primeiro contato que a equipe iria manter com o Chefe do P.I e com o Cacique. A impressão, confirmada em dias posteriores, era a de que os militares estavam interessados em acompanhar nosso trabalho, algo pelo que sabemos, incomum nas experiências de campo dos antropólogos brasileiros (UFSC/FAPEU/ELETROSUL, 1980, p. 8). 
Além da presença militar, a equipe coordenada pelo prof. Silvio também teve a surpresa de encontrar a comunidade Kaingang bem organizada politicamente para a reivindicação de seus direitos enquanto povo indígena afetado pelo empreendimento hidrelétrico. Conforme descrevem, os Kaingang mostraram já possuir amplo conhecimento sobre - Projeto Uruguai e a possibilidade de implantação da barragem Machadinho pela Eletrosul. O Relatório também informa que:

\begin{abstract}
Efetivamente, os Kaingang do PI Ligeiro revelaram um alto senso de compreensão e discernimento da questão criada pela construção da barragem Machadinho. Eles sabem que a área em torno da reserva é formada por minifúndios e que não há condições para uma indenização em terras, para compensar parte que será inundada. Sabem também que os benefícios desejados devem ser encaminhados diretamente para o próprio grupo pela Eletrosul, pois temem os riscos de extravio desses mesmos benefícios caso eles sejam canalizados via FUNAI. Por último, pretendem que as compensações cheguem bem antes das águas, pois têm experiência da política do "fato consumado" (UFSC/FAPEU/ELETROSUL, 1980 , p. 10-11).
\end{abstract}

Importante também destacar a tensão social e psicológica que o próprio anúncio da implantação de projetos hidrelétricos causa nas populações locais, conforme já havia sido assinalada desde o estudo antropológico anterior para a Eletrosul (1978). Desse modo, os prejuízos considerados "indiretos" passam a ser vivenciados cotidianamente pela comunidade, gerando expectativa de insegurança coletiva quanto ao futuro que se aproxima.

Não obstante um cronograma de trabalho bastante limitado pelo curto tempo disponível, a equipe de pesquisadores ressaltou seus os esforços para apresentar à empresa "um quadro bastante aproximado da realidade vivida pelos indígenas localizados na bacia do rio Uruguai" (UFSC/FAPEU/ELETROSUL, 1980, p. 8). Do mesmo modo, enfatizara princípios que seriam seguidos na condução dos estudos, tais como:

A noção de que os indígenas formam povos étnica e culturalmente diferentes da sociedade nacional e por isso tem direitos inalienáveis, previstos na legislação nacional e internacional, permeia todo nosso trabalho. Esperamos 
que a hipótese, levantada desde o início dos trabalhos pertinentes à elaboração deste relatório, seja efetivamente considerada: a de que as terras indígenas sob nenhuma justificativa deverão ser objeto de utilização pela sociedade nacional. Se tal não ocorrer, entretanto, será preciso considerar que os índios devem ser ouvidos e respeitados, em qualquer projeto de acordo. E neste caso, à FUNAI cabem tarefas específicas, na sua condição de tutora, referentes ao resguardo dos interesses indígenas (UFSC/FAPEU/ELETROSUL, 1980, p. 7-9).

Nesse sentido, o conteúdo produzido no Relatório Antropológico de 1978 por Silvio Coelho dos Santos e sua equipe andava na contramão do projeto de exploração hidroelétrica proposto para a bacia do Rio Uruguai. O Relatório ainda destaca as condições pelas quais os povos indígenas estavam sendo submetidos, apontando inclusive a responsabilidade do Estado perante as violações de seus direitos, e, portanto, não recomenda a construção das barragens sobre o território destas populações. Algumas alterações, simplificações e/ou descontextualizações do relatório Projeto Uruguai - Os Barramentos e os Índio (1978), apresentadas em posterior publicação intitulada Estudo de Inventário Hidroenergético (1979), organizada pelo CNEC para a Eletrosul, apontam também para as limitações a esse atribuído ineditismo da Eletrosul na contração de uma equipe de pesquisadores para realização de levantamentos antropológicos naquele momento.

As pesquisas de campo realizadas pela equipe de antropólogos coordenada por Silvio Coelho dos Santos deram origem a um segundo relatório sobre as Consequências da Construção da Barragem Machadinho para os índios do P.I Ligeiro (RS) (UFSC/FAPEU/ELETROSUL, 1980). Este relatório, cujas cópias podem ser encontradas no acervo do NEPI, consiste num estudo sobre a situação dos indígenas da Terra Indígena Ligeiro (RS), na época ainda Posto Indígena, e teve como objetivo principal, segundo os autores, "aprofundar o conhecimento sobre as consequências que sofreriam os indígenas aldeados no Posto Indígena Ligeiro (RS) em decorrência da construção da barragem Machadinho, localizada no Rio Pelotas (Uruguai)" (p. 1).

No que se refere ainda à relação entre índios e regionais no entorno da TI Ligeiro (RS), os/as pesquisadores/as descrevem que além dos 
preconceitos, estereótipos e manifestações veladas de racismo (UFSC/FAPEU/ELETROSUL, 1980, p. 105), os indígenas eram identificados pelos colonos como "bugres", e classificados como "bons e maus", conforme relatam a seguir:

Índio bom é aquele que não bebe e os maus são os que vivem bêbados, 'aqueles que incomodam' [...] Além do temor generalizado e difuso que os colonos revelam pelos indígenas, consideram-nos ainda 'sujos', de 'baixa capacidade intelectual' e 'sem cultura'. Paulatinamente, o índio se transforma em 'bugre' termo que na região tem fortes conotações pejorativas e que sintetiza, de maneira eficiente, todos os preconceitos revelados pelos componentes da sociedade regional (UFSC/FAPEU/ELETROSUL, 1980, p. 104-105).

O Relatório também descreve a reunião do Conselho Indígena, realizada no dia 18 de maio de 1980, na Sede do Posto, da qual os pesquisadores puderam participar. Naquela oportunidade, vários conselheiros indígenas se manifestaram aos/às antropólogos/as com um tom de indignação e desabafo, para dizer de seu cansaço quanto às promessas e "boas intenções" da Funai, bem como de seus temores quanto ao possível ilhamento que as águas trariam para a reserva como um todo, "visto que a atual ponte de madeira sobre o Rio Ligeiro e uma parte da estrada que corta a reserva serão alagadas" (UFSC/FAPEU/ELETROSUL, 1980, p. 121). A preocupação e tensão psicológica manifestadas pelos indígenas nesta reunião do Conselho Indígena foram detalhadamente descritas, entre as quais destaco:

Talvez a manifestação mais dramática dessa ansiedade coletiva seja o seguinte comentário de uma mulher da Sede: "Quanto tempo vai durar a barragem? Tamo com medo de inundá a área. Minha irmã e eu tamo pensando em fazê uma canoa"; ou o desabafo de uma criança de cerca de 7 anos, na presença de duas das pesquisadoras: "Vamo tudo morrer embaixo dágua"! (UFSC/FAPEU/ELETROSUL, 1980, p. 121-122, destaques meus).

Diante das evidências dos efeitos negativos da implantação desta hidrelétrica à população indígena Kaingang, mesmo no período anterior à construção da obra - como o estresse psicológico gerado pelas 
incertezas relacionadas à inundação de suas terras -, os antropólogos incluíram as seguintes recomendações neste estudo complementar:

Indenização justa em troca do alagamento parcial de suas terras, com prioridade de indenização sobre os demais segmentos; informação à comunidade indígena sobre a implantação da hidrelétrica, evitando a relocação prematura de casas e lavouras localizadas nas terras a serem alagadas; exigência de participação da Funai no acompanhamento do processo, bem como a ampliação de projetos sociais e econômicos; implementações de ações integradas para minimizar o estresse psicológico desta população; e, finalmente, assegurar que as perdas sofridas fossem compensadas atendendo os interesses dos índios (UFSC/FAPEU/ELETROSUL, 1980, p. 132135).

O envolvimento e atuação de Silvio Coelho dos Santos, uma década antes das exigências legais de estudos de impacto ambiental e social, na implantação da UHE Machadinho - usina inicialmente priorizada pelo Projeto Uruguai juntamente com a UHE Itá14_, foi fundamental para que parte dos territórios indígenas Kaingang e Guarani, inicialmente áreas previstas de serem alagadas, fossem conservados devido à sua sugestão acatada para mudança do eixo da barragem. Por conta dos seus estudos, a Eletrosul deferiu algumas das recomendações propostas no levantamento apresentado pelo antropólogo. Como salientou Souza (1997), a eficácia dos trabalhos do prof. Sílvio neste caso "evitou consequências nefastas à Área Indígena (Al) Ligeiro" (p. 1) no Rio Grande do Sul, e assegurou, em grande medida, os direitos territoriais das populações Kaingang e Guarani que habitam o território em questão.

A mudança do eixo da barragem Machadinho resultou na não alagação da parte da TI Ligeiro (RS), inicialmente prevista, ao mesmo tempo que a eliminação da barragem de contenção de Paim Filho salvaguardou as terras indígenas de Forquilha, em Cacique Doble (RS). Essas alterações foram resultado das sugestões apresentadas pelos estudos dos antropólogos da UFSC, sobretudo o de 1978. Entretanto, como irão apontar posteriormente no Estudo Etnográfico da Usina hidrelétrica Machadinho (1998), ainda que as suas terras não tenham sido alagadas, as populações indígenas dessas TIs ainda estão localizadas na

${ }^{14}$ Para uma análise aprofundada sobre este caso, ver Reis (1998). 
área de influência do empreendimento, sofrendo até hoje algumas consequências sobre seu modo de vida.

\section{Os índios em movimento no Sul do país e a luta pela terra nos anos 1970 e 1980}

Ao mesmo tempo que os estudos e pesquisas de campo estavam sendo realizados pelo antropólogo Silvio Coelho dos Santos e sua equipe durante os anos 1970 e 1980 nos territórios indígenas selecionados para a implantação das hidrelétricas previstas no Projeto Uruguai, intensas movimentações dos indígenas na região Sul estavam acontecendo na luta pela retomada de suas terras e enfrentamento às inúmeras situações de violências sofridas por estes povos.

Ao longo de toda a segunda metade do século XX, neste contexto de exploração madeireira que se realizara nos postos indígenas, tensões entre os indígenas e os agentes indigenistas oficiais e da sociedade regional se acirraram gradativamente, refletindo as relações assimétricas de poder que se estabelecia. Os chefes de postos desempenhavam um papel centralizador e controlador nas decisões que tomavam autoritariamente na mediação dos postos de trabalho para realização das atividades para o desmatamento daquelas terras, parte dos territórios Kaingang. De acordo com Brighenti e Wittmann (2014), a exploração madeireira na região atravessou dois ciclos de: o primeiro através da exploração via balsa no Rio Uruguai, e o segundo nas florestas de araucária, sendo a década de 1960 o auge dessa expansão madeireira, e a década de 1970, o esgotamento dessas florestas (p. 122).

As transformações ocorridas durante a transição do órgão indigenista de SPI para Funai, contudo, não se refletiram em mudanças sobre essa exploração econômica dos postos e mão-de-obra indígena, pois mesmo com a Funai ela continuou, até o esgotamento das araucárias. Essa situação também é abordada por Almeida (2015):

os militares, não mais personificados na pessoa de Rondon e engajados no desenvolvimentismo no Brasil por meio do "milagre econômico", transformaram o órgão indigenista numa agência burocrática e extremamente capitalista. $O$ patrimônio indígena foi racionalizado e 
transformado em programas e projetos de desenvolvimento. Entre 1940 e 1988 o PI Xapecó viu o "pinheiro" Araucária transformar-se no protagonista da emancipação econômica, contudo, os indígenas não se mantiveram calados e promoveram insurreições. Ao percorrer tais décadas fica evidente que o indigenismo dos tempos de Vargas e Rondon é muito distinto do indigenismo moralizante dos militares (p. 362).

Foi nesta conjuntura que, em 1975, a Funai passou a implementar os Projetos de Desenvolvimento Comunitários (PRODEC) nos Postos Indígenas, sob a justificativa de agregar a renda obtida através destes projetos de exploração de madeira na região à "Renda Indígena" do PI, a qual era recolhida ao órgão de assistência para o pagamento de salário do pessoal técnico e administrativo da Funai, bem como (deveria ser) destinada ao financiamento do precário atendimento prestado aos indígenas, nas áreas de saúde e educação, entre outras (NACKE et al., 2007, p. 51). Importante dizer que a principal devastação florestal ocorrida neste território indígena foi objeto de investigação da Comissão Parlamentar de Inquérito presidida por Jader de Figueiredo, sendo relatada no importante documento Relatório Figueiredo (CORREIA, 1967).

Apesar de sentirem-se acuados pela situação de opressão que se configurava, os indígenas da TI Xapecó não aceitaram passivamente à dilapidação de seu patrimônio, apesar dos castigos que recebiam por parte dos encarregados do órgão oficial lotados na área15. Assim, estimulados por diversos grupos da sociedade civil e pela Igreja (através do CIMI e Comissão Pastoral da Terra), os indígenas iniciam uma série de articulações, participando de encontros indígenas regionais, da formação

\footnotetext{
15 Brighenti e Wittmann (2014) descrevem a crueldade que consistia nos dois tipos de castigos sofridos pelos povos Kaingang e Guarani dessa região. Segundo ele, os castigos consistiam na "transferência de toda a família para outra TI, sem direito a seus pertences, e o terrível "tronco", no qual a pessoa ficava com o tornozelo preso entre duas madeiras cravadas no chão em forma de forquilha e amarradas na parte superior, de modo a provocar dor pelo amassamento do osso. Essa tortura foi bastante empregada pelos chefes de posto no Sul do Brasil, conforme aponta o inquérito elaborado por Jáder de Figueiredo: "o tronco era o mais encontradiço de todos os castigos, imperando na $7^{\text {a }}$ Inspetoria. Consistia na trituração do tornozelo da vítima". Houve casos de fratura da perna com sequelas permanentes. Para manter a ordem e punir os revoltosos, os chefes de posto faziam uso da polícia indígena, força instituída pelo SPI. A justificativa para a existência desse corpo disciplinador era a segurança da comunidade, porém foi largamente utilizado para repressão" (p. 126-127). Especificamente, os Guarani foram duplamente controlados nos postos indígenas da região Sul, para onde passaram a ser transferidos pelo órgão tutelar. Neles, estavam submetidos aos chefes de posto e aos caciques de povos de outras etnias, como os Kaingang, "que considerava os Guarani hóspedes em suas terras e, portanto, sem direitos políticos" (BRIGENTI, 2014, p. 133). Além da Terra Indígena Xapecó (SC), situações como essas se sucederam também em várias outras, como na TI Cacique Doble (RS), ou Nonoai (RS).
} 
de Conselho de Autoridades, entre outras estratégias. Desse modo, conseguem, no ano de 1978, a expulsão de 300 famílias de arrendatários levadas pelo SPI e mantidas pela Funai, e do chefe de Posto da TI Xapecó (SC), além da retirada de cerca de três mil famílias de colonos da TI Nonoai (RS). Os Kaingang e Guarani organizados passaram a pressionar os posseiros e a Funai para a desintrusão imediata de suas terras (CASTRO, 2011 , p. 113). Representando os indígenas do Paraná, Ângelo Cretã, reconhecida liderança Kaingang, morto em 1980, comentava sobre esse processo de retomada das terras pelos indígenas, em entrevista concedida ao documentário Terra dos Índios (1979), produzido e dirigido por Zelito Viana:

Como nós começamos aquilo ali e vencimos, fumos até o fim, por que não há de limpar as outras áreas? Imo lá pro Nelson [Xangrê] ajudar ele tirar aqueles intrusos de lá. É pesada a situação lá, mas se nós ganhamos aquela de Rio das Cobras, ganhamos essa aqui [em Mangueirinha], e aquelas de Chapecó e Nonoai. Nem que morra alguém, mas sobra muita gente. Vamos larga-Ihe o pau e limpar as terras indígenas (CRETÃ apud TERRA DOS ÍNDIOS, 1979).

Uma série de mobilizações e movimentações indígenas ${ }^{16}$ se realizou nas diversas regiões e Tls do Brasil a partir da década de 1970, as quais consistiram em estratégias políticas de luta e resistências dos povos indígenas para garantir o direito de exercerem suas tradições, costumes e identidade em seus territórios originários (CARDOSO DE OLIVEIRA, 1988). Especificamente, no Sul do país, os conflitos foram extremamente acirrados com os regionais não indígenas, compostos por colonos, conforme relatam Brighenti e Wittmann (2014):

\footnotetext{
${ }^{16}$ Baniwa (2006) ao abordar sobre a importância do Movimento Indígena no Brasil, define este como "o conjunto de estratégias e ações que as comunidades e as organizações indígenas desenvolvem em defesa de seus direitos e interesses coletivos" (p. 58). Entretanto, o autor enfatiza a noção do líder indígena Daniel Munduruku para esclarecer o sentido concreto do que é e como se constitui o movimento indígena: "O líder indígena Daniel Mundurucu costuma dizer que no lugar de movimento indígena dever-se-ia dizer índios em movimento. Ele tem certa razão, pois não existe no Brasil um movimento indígena. Existem muitos movimentos indígenas, uma vez que cada aldeia, cada povo ou cada território indígena estabelece e desenvolve o seu movimento. Mas as lideranças indígenas brasileiras, de forma sábia, gostam de afirmar que existe sim um movimento indígena, aquele que busca articular todas as diferentes ações e estratégias dos povos indígenas, visando a uma luta articulada nacional ou regional que envolve os direitos e os interesses comuns diante de outros segmentos e interesses nacionais e regionais" (BANIWA, 2006, p. 58).
} 
[E]m Rio das Cobras/PR, com a expulsão de 160 famílias de arrendatários em janeiro do mesmo ano. Quatro meses mais tarde, em Nonoai/RS, mais de mil famílias de arrendatários também foram expulsas. Seguiu-se o fechamento da serraria na TI Mangueirinha/PR e a expulsão de arrendatários em Guarita, Cacique Doble e Ligeiro/RS. A mobilização indígena contra as ações da FUNAI incidiu diretamente sobre os negócios do órgão indigenista com empresários e políticos regionais que se beneficiavam das ilegalidades e das violências impostas aos Kaingang. Líderes foram assassinados, como Ângelo Cretã/PR, em 1980, e Marçal de Souza Tupã'i/MS, em 1983, e outros sofreram tentativas de assassinato, como o cacique de Nonoai/RS Nelson Xangrê que, sem proteção, teve que deixar o cacicado e abandonar a Terra Indígena (p. 129-131).

\section{Mobilização dos indígenas Kaingang e Guarani na TI Nonoai (RS)}

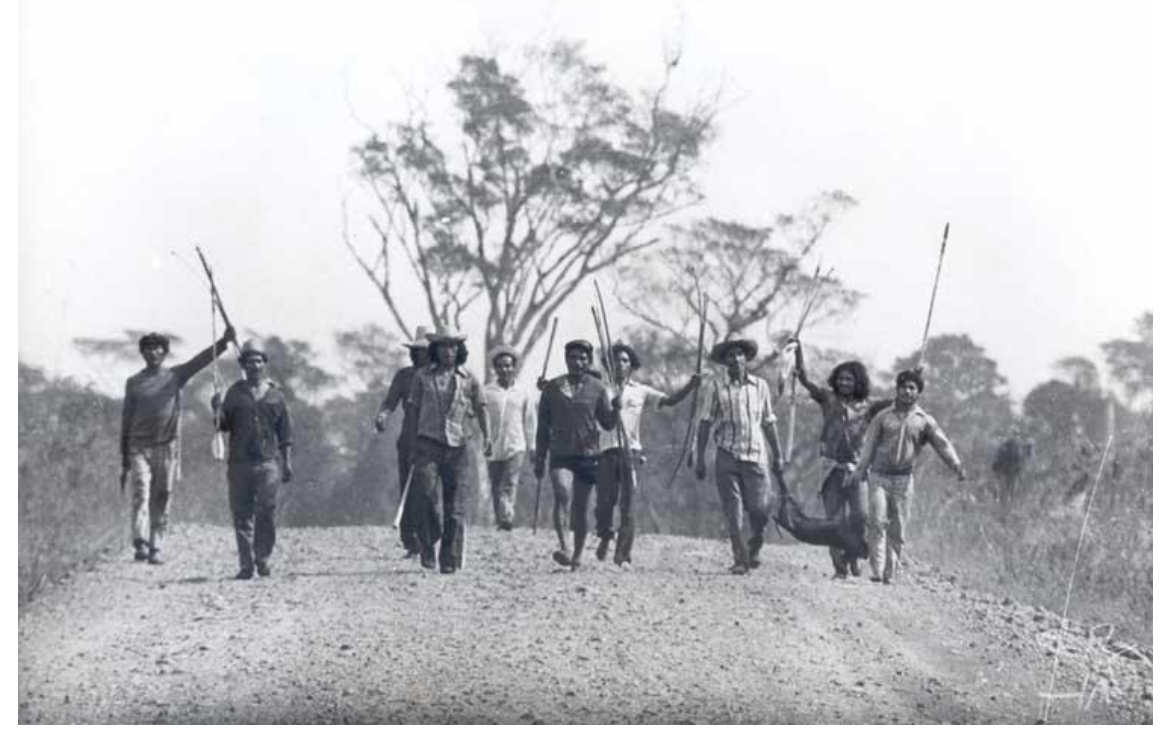

Fonte: Instituto Socioambiental (ISA), autoria de Assis Hofmann (1978).

As disputas para as retomadas de terras antigas pelos indígenas no Sul do Brasil a partir da década de 1970 têm demonstrado à sociedade regional que, apesar das inúmeras situações de intrusão e violências a que estavam sendo submetidos, somado ao não reconhecimento pelos colonos de sua identidade indígena, eles estavam organizados e 
mobilizados para lutar em defesa de suas terras e direitos, visto a total omissão da Funai diante das denúncias que constantemente realizavam (D’ANGELIS, 1984; CASTRO, 2011 ).

Um caso significativo foi a retomada das terras indígenas da $\mathrm{TI}$ Chimbangue, anteriormente denominada Toldo Irani, apontada como uma das áreas indígenas afetadas diretamente pelo Projeto Uruguai nos estudos realizados pela equipe de pesquisadores coordenada pelo prof. Silvio Coelho dos Santos em 1978. Os Kaingang do Toldo Chimbangue sofreram longa situação de exílio, afastados por longo tempo de suas terras, como nos informa Brighenti (2012):

Os Kaingang do Toldo Chimbangue durante pelo menos meio século ficaram afastados de suas terras, espalhados pela região, não mais reconhecidos pelos regionais em sua identidade Kaingang. Foram considerados "caboclos" ou "bugres", termos pejorativos a sua identidade Kaingang, entretanto, mantiveram-se unidos pela memória coletiva e pela resistência de algumas famílias que permaneceram acampadas nas margens do rio Irani, vivendo de agregados em suas terras (p. 37-38).

Ao abordar sobre o histórico de contato dos Kaingang do Oeste Catarinense com as frentes de colonização desde o século XVIII, D’Angelis (1984) destaca que a luta pela reconquista da TI Chimbangue pelos indígenas contou também com estratégias jurídicas e políticas, como a carta elaborada pela comunidade Toldo Chimbangue e encaminhada à Presidência da República em Julho de 1984, exigindo a tomada de posição do Governo diante da situação conflituosa que se configurava entre indígenas e colonos na região.

Como resultado das ações e articulações dos indígenas, e contando com o apoio de segmentos da sociedade civil (como o CIMI), os Kaingang da TI Chimbangue conseguiram a recuperação e demarcação de suas terras, que começou a se efetivar após a realização do primeiro Laudo Antropológico no Brasil, elaborado pelas antropólogas Ana Lange (Funai), Neusa Maria Sens Bloemer e Aneliese Nacke (UFSC), em 1984 (NACKE; BLOEMER; LANGE, 1984; BLOEMER e NACKE 1996).

Sobre este processo histórico de retomada das terras do Chimbangue pelos indígenas, Nacke e Bloemer (2007) informam que 
[a]locados em um espaço restrito, os Kaingang reagiram e se confrontaram com os novos proprietários das terras, o que resultou em muita hostilidade, havendo, inclusive, agressões físicas entre os moradores regionais e a população indígena. Foi no limite desta convivência insuportável que a Funai nomeou o Grupo de Trabalho com o objetivo de elaborar um relatório que pudesse fundamentar a ocupação imemorial das terras pelos Kaingang. Em julho de 1984, foi nomeado através da Funai o Grupo de Trabalho composto por antropólogos, agrimensores, técnicos agrícolas; houve, inclusive, a necessidade da presença da Polícia Federal, pois um clima de tensão havia se estabelecido, não só na área em litígio, mas no município de Chapecó. Este processo se estendeu até 30 de dezembro de 1985, quando finalmente, por meio de um acordo político, foi determinado que seriam reconhecidos e demarcado 988 hectares; metade das terras reivindicadas pelos Kaingang do Toldo Chimbangue. A decisão foi oficializada pelo Decreto Presidencial n. 92.253/85 (p. 61).

\section{Considerações acerca dos povos indígenas e projetos de desenvolvimento na América Latina: relações, redes e articulações reveladas no acervo}

Os efeitos sociais decorrentes da implantação de barragens hidrelétricas nos países da América Latina, especialmente entre as décadas de 1970 a 1980, para atender aos planos estratégicos de desenvolvimento propostos de integração econômica entre os países, a exemplo da Comissão de Integração Elétrica Regional (Cier) ${ }^{17}$, foram severamente denunciados no cenário internacional. Somente em relação aos deslocamentos forçados das populações locais pela implantação destes empreendimentos, os números chegam à casa de milhares.

De acordo com dados identificados por Catullo (1996) sobre a construção de empreendimentos hidrelétricos na América Latina entre os anos 1970 e 1980, as pessoas deslocadas de suas terras constituíram um

\footnotetext{
${ }^{17}$ Conforme a minuciosa análise de Nuti (2006) sobre a integração energética na América do Sul, a criação da Comissão de Integração Elétrica Regional (Cier), em 1965, consiste num marco dessa proposta e são notórios seus reflexos na política energética brasileira. Segundo as informações da autora, este organismo internacional constitui-se, inicialmente, pela integração entre um comitê central e os comitês nacionais de diversos países membros da América Latina (entre eles o Brasil), tendo como objetivo "promover em caráter permanente o intercâmbio de informações, experiências e trabalhos técnicos entre empresas de energia elétrica da América do Sul." (ELETROBRÁS, 2004, p. 16,apud NUTI, 2006, p. 19).
} 
dos fenômenos mais críticos de sua implantação. Segundo ela, as estimativas apontavam que a hidrelétrica Miguel Alemán, no México, afetou 22.000 pessoas; no Brasil, a hidrelétrica de Sobradinho deslocou 65.000 pessoas e a de Tucuruí cerca de 30.000. A hidrelétrica de Salto Grande (Argentina-Uruguai) obrigou a reassentar, na margem argentina, a cidade de Federación (7.000 pessoas) e, na margem uruguaia, a populações de Belén e Villa Constitución (4.500 pessoas); a hidrelétrica Yaciretá (Argentina-Paraguai) deslocou 40.000 pessoas em ambas as margens do Rio Paraná, constituindo naquele momento o maior reassentamento urbano, a nível mundial, em decorrência de instalação de usinas hidroelétricas.

Conforme apontam diversos autores ${ }^{18}$, os projetos hidrelétricos implantados durante o regime militar no Brasil, assim como nos demais países da América Latina, geraram uma série de efeitos deletérios tanto às pessoas quanto ao meio ambiente, desencadeando uma série de reações politicamente organizadas através de movimentos sociais de resistência popular contrários a esses empreendimentos, a exemplo da Comissão Regional dos Atingidos por Barragens (CRAB) ${ }^{19}$ no Brasil.

Uma das grandes surpresas que tive ao pesquisar no acervo do prof. Silvio decorreu da leitura dos documentos que encontrei em uma caixa etiquetada como "Periódicos", localizada no "rodapé" de uma estante de metal que organiza revistas acadêmicas do Brasil e de diversos países do mundo, algumas das quais o prof. era assinante. Deparei-me com seis edições do "Centro Antropológico de Documentación de América Latina", também referenciado como CADAL, os quais consistem em documentos mimeografados dos anos 1976 e 1977, organizados por alguns antropólogos e entidades indigenistas da América Latina, com o intuito de dar visibilidade às situações vividas pelas diversas populações

\footnotetext{
${ }^{18}$ Cf. Bartolomé (1980), Sigaud (1986), Ribeiro (1987), Martins-Costa (1989), Magalhães (1996), entre outros.

${ }^{19}$ A Comissão Regional dos Atingidos por Barragens (CRAB) foi criada no ano de 1979, com sede na cidade de Erexim (RS), em consequência da organização da população local atingida pelas barragens na bacia do rio Uruguai na região Sul do país, transformando-se posteriormente em porta-voz dos atingidos por barragens em todo território nacional ao constituir-se, em 1991, no Movimento Nacional dos Atingidos por Barragem (MAB). Para uma análise aprofundada sobre todo o processo de mobilização e reação popular à proposta de implantação de barragens na bacia do rio Uruguai, ver Reis (1998), a qual acompanhou em sua pesquisa etnográfica a organização e reassentamento dos camponeses do Alto Uruguai durante a construção da hidrelétrica de Itá (SC). Veja-se, também, Sigaud (1986; 1988) e Scherer-Warren; Reis (1986, 1989).
} 
indígenas e, também, promover o conhecimento de declarações e manifestos produzidos por Organizações Indígenas dos "Grupos Étnicos" e intelectuais dos países latino-americanos naquele período, como a Declaração de Barbados. As seis edições que encontrei no acervo do NEPI são datadas em agosto de 1976; janeiro, julho, setembro e dezembro de 1977; e março de 1978. No geral, são organizadas em seções que se assemelham a informativos das situações indígenas de cada país, como Argentina, Bolívia, Brasil, Colômbia, Chile, Equador, México, Paraguai, Peru e Venezuela.

O documento de agosto de 1976, por exemplo, apresenta nos informes da seção "Brasil" as Atas de Assembléias realizadas em 1975 pelos chefes indígenas do Pará, assinada como "Missão Cururu", e do Mato Grosso, assinada como "Meruri", nos quais são transcritas as falas de cada representante indígena nas reuniões que realizavam para discutirem sobre estratégias de luta por seus direitos, problemas ligados à atuação da Funai, assassinato de parentes e esbulho de suas terras tradicionais. O relato de Mário Juruna, liderança política Xavante, salientava que

[o] Governo vai se sentir envergonhado diante dos países estrangeiros se continuar matando índio como quer e quando quer. Precisamos estudar pra defender a classe indígena e viver legitimamente como índio.

Ou mesmo o de Miguelão, Bororo:

Não somos nós que estamos roubando terra. O branco é como tatu, onde entra estraga tudo. Pode ter tudo que ele que roubar e ainda grafam. Escreve seu roubo no papel que é pra ter mais firmeza. Vamos trabalhar mais unidos para defender nossa terra.

Entre as denúncias constantemente relatadas nos documentos sobre casos de genocídio dos indígenas em vários países da América Latina naquele momento, há uma elaborada pelo Conselho Indigenista Missionário $(\mathrm{CIMI})^{20}$ que se refere às violências e espancamentos de

\footnotetext{
${ }^{20}$ O Conselho Indigenista Missionário (CIMI) é um órgão criado em 1972 pela Conferência Nacional dos Bispos do Brasil (CNBB), tendo uma atuação junto às populações indígenas do Brasil desde sua institucionalização. O apoio aos povos e movimentos indígenas no Sul do Brasil, sobretudo nos anos 1970 e 1980, é profundamente abordado na tese de Brighenti (2012).
} 
indígenas no Sul, especificamente em Xanxerê (SC). Para exemplificar a situação de violência física oriunda de oficiais e "brancos" vivida pelos indígenas da região oeste de Santa Catarina, o documento de 1976 relata que

[n]o dia 12 de agosto, p. p., a menor Belmiria Vitorino Caneró, enquanto se dirigia para a escola, foi agredida por um guarda florestal, que tentou agarrá-la à força e possivelmente, seduzi-la. Neste dia, os guardas da área florestal estiveram na casa de Antônio Domingos, tirandoo violentamente de seu rancho e batendo-lhe bárbara e gratuitamente. Sua mulher, apavorada, fugiu para o mato, com seus filhos, quando pode ainda presenciar os guardas matando a tiros, os cachorros da casa enquanto outros, agrediam a seu marido. Quando retornou, não encontrando o marido temeu que ele estivesse morto, jogado no mato e apodrecendo no tempo. Foi constatado por pessoa ligada ao CIMI, que este índio, depois de espancado, fora amarrado, ficando atado três dias.

Outro documento do CADAL, ao apresentar uma série de estudos latino-americanos e o papel das universidades para a "libertação dos indígenas na América Latina", referem-se também aos projetos de desenvolvimento que se consolidavam no Brasil na década de 1970, como hidrelétricas e rodovias, denunciando casos de genocídio e etnocídio das populações indígenas dos territórios onde se instalavam. Igualmente, na edição de setembro de 1977, um estudo não assinado sobre A Política de Genocídio contra os Índios é apresentado de forma sistemática, manifestando também o trabalho de alguns antropólogos no combate à "política empresarial da Funai" para contribuir aos projetos de desenvolvimento dos governos militares naquele momento.

De forma especial, o Documento n. 5, de 197821, apresenta a Situação do Índio no Brasil e, entre os relatos, há um específico do prof. Silvio, assinado S.C.S (assim como as demais autorias), que discorre sobre

\footnotetext{
${ }^{21}$ Nesse mesmo ano, ocorre a publicação do livro "O Homem Índio Sobrevivente do Sul”, escrito por Silvio Coelho dos Santos em decorrência de sua participação no seminário "O Índio sobrevivente do Sul", realizado em 1976, em Porto Alegre. Nesta ocasião, foi criada a Associação Nacional de Apoio ao Índio (ANAI), organização que em alguns locais do Brasil denominou-se Pró-Índio. Segundo reconstitui Santos (2005): "Foi a primeira vez que, durante o regime militar, um número expressivo de antropólogos, advogados religiosos, indigenistas e lideranças indígenas e civis se reuniu para explicitar e defender os direitos dos povos minoritários. Desse seminário resultou a fundação da Associação Nacional de Apoio ao Índio (ANAI), entidade para a qual doei os direitos autorais do livro acima referido. Logo em seguida, ainda como efeito positivo desse encontro, surgiram as Pró-Índio de São Paulo e do Rio de Janeiro” (p. 73).
} 
a teoria da aculturação, em vigor naquele período. Ao encontrar esse documento, foi inevitável que esse "fio" me levasse à "trama" que consistiu na primeira Reunião de Barbados, da qual o prof. Silvio participou, de grande contribuição para a tomada de novos rumos da antropologia latino-americana, como compromisso com a defesa dos direitos indígenas.

Foi no ano de 1971, na ilha caribenha de Barbados, que se realizou o Simpósio sobre Fricção Interétnica na América do Sul,22 no qual se reuniu um grupo de antropólogos 23 do continente americano. Ao final do evento, esses antropólogos redigiram um importante documento denominado "Declaração de Barbados: Pela Libertação do Indígena", com o intuito de apresentá-lo à opinião pública para o esclarecimento do "grave problema continental e para a luta de libertação dos povos indígenas". Nele anunciaram também os novos postulados e atribuições ao que convencionaram chamar de "antropologia comprometida"24. A participação do prof. Silvio Coelho dos Santos foi propiciada pelo convite que recebeu devido aos seus trabalhos que já desenvolvia junto aos povos indígenas do sul do Brasil25, como ele mesmo relata:

Em 1970, por exemplo, eu havia publicado o livro $A$ integração do índio na sociedade regional: a função dos postos indígenas em Santa Catarina (Imprensa Universitária, UFSC), como uma das etapas do doutorado na USP. Em função da circulação desse livro no exterior,

\footnotetext{
${ }^{22}$ Esta reunião teve como objetivo principal analisar as relações interétnicas nos países da América do Sul de forma a consolidar um maior comprometimento da prática antropológica com as populações desprivilegiadas nos planos de ações coloniais, dos órgãos estatais e multilaterais (OLIVEIRA, 2004, p. 13).

${ }^{23}$ Dentre os quatro antropólogos brasileiros participantes e presentes nessa reunião, entre eles Sílvio Coelho dos Santos (UFSC), apenas Darcy Ribeiro assinou esta Declaração, dada sua condição de exílio no Chile, por questões de segurança em meio ao regime militar que imperava no Brasil.

${ }^{24}$ Sobre esta Declaração, Silvio Coelho dos Santos esclarece que: "No Brasil, no auge do autoritarismo, essa Declaração estimulou diferentes profissionais para o exercício do que se convencionou chamar, à época, de Antropologia Comprometida" (SANTOS, 1998, p. 85). No que tange à importância da Reunião de Barbados para a Associação Brasileira de Antropologia neste período, veja-se Santos (2006) e Bartolomé (2006).

${ }^{25}$ No que tange ao livro A integração do índio na sociedade regional: a função dos postos indígenas em Santa Catarina, que correspondeu a uma das etapas do doutorado na USP pelo autor, em 1969, este não conseguiu passar em primeira instância pela censura universitária que se instaurou naquele período. Segundo relata o próprio antropólogo: "Devido a denúncias, esse livro, quando estava em fase final de edição (dezembro de 1969), foi apreendido na Imprensa Universitária pela Polícia Federal. Sua liberação ocorreu graças às relações de minha família e ao apoio do reitor Ferreira Lima. Em 19 de fevereiro de 1970, o tenente-coronel Ary Oliveira, delegado regional do DPF-SC, assinou o Certificado 02/70 liberando a obra" (Santos, 2006, p. 47).
} 
recebi um convite para participar, em 1971, da Reunião de Barbados, realizada sob o patrocínio da Universidade de Berna (Suíça) e do Conselho Mundial de Igrejas, tendo como foco a violência das relações entre índios e brancos na América Latina. O documento final dessa reunião exortou os antropólogos a exercerem suas responsabilidades em relação às minorias indígenas, ao mesmo tempo em que expressou severas críticas às políticas governamentais e aos papéis assumidos pela Igreja em relação à dominação colonial dos índios. Essa experiência permitiu a ampliação do meu comprometimento e de outros colegas brasileiros com as minorias indígenas do País, que estavam sendo vilipendiadas pelos projetos desenvolvimentistas impostos pelos governos militares (SANTOS, 2006, p. 47).

A produção literária realizada por esses antropólogos consistia em publicações como livros, boletins, artigos, cadernos, correspondências, entre outros, que informavam sobre as situações de vida dos povos indígenas em seus contextos nacionais entre os países latinoamericanos. Uma das obras de referência, também localizada no acervo, é intitulada: The situation of the indian in South America - Contribuitions to the study of inter-ethnic conflict in the non-Andean regions of South of America (1972), a qual o prof. Silvio também colaborou com o artigo "The Situation of the Indians of Southern Brazil" (1972, p. 334-337).

Nasce, neste momento histórico, uma antropologia em reação às grandes políticas de desenvolvimento que se espalharam pelos países da América Latina, entre os anos 1960 e 1980, implantadas por governos militares ditatoriais, cujos projetos econômicos que promoviam resultaram em genocídios, deslocamentos compulsórios e perdas territoriais, entre outros, de vários povos indígenas (DAVIS, 1978; BARTOLOMÉ, 1980, 1983; ARZE QUINTANILLA, 1983; SANTOS; ANDRADE, 1988).

A Reunião de Barbados e outros eventos, documentos e articulações que ocorreram em defesa dos direitos dos povos indígenas neste contexto das ditaduras civis-militares na América Latina, produziram reflexões e mobilizações extremamente importantes para a divulgação e o enfrentamento das diversas situações de violências que, infelizmente, permanecem até os dias atuais. 
Nesse sentido, a publicização de documentos, como o Relatório Figueiredo, e outras fontes de informação sobre os diversos contextos de violências sofridas pelas populações indígenas no Brasil e demais países da América Latina são, a meu ver, urgentes, e podem trazer grandes contribuições à (re)constituição de mais fiéis e legítimas histórias que revelem, de modo explícito, os acontecimentos que são fundamentais para a compreensão desta presente e atual conjuntura em que vivem cada um dos povos originários latino-americanos. Vemos, a exemplo do Projeto Uruguai e Belo Monte, que muitos projetos de desenvolvimento concebidos durante a ditadura civil-militar têm sido retomados e "reformulados" por sucessivos governos atualmente, motivo pelo qual são necessários os esforços de encontrar os registros que possam contar, sob outras perspectivas, os meandros ainda obscurecidos de cada acontecimento.

Assim como foi possível encontrar vestígios (registros) de algumas das situações vividas pelos povos indígenas no Sul do Brasil a partir do acervo e dos estudos antropológicos realizados pelo antropólogo Silvio Coelho dos Santos, creio e faço votos de que surjam outros lampejos de histórias ainda não contadas oficialmente sobre as violações e desafios a que são submetidos os povos indígenas e tradicionais. Que essas histórias e vozes ressoem o quanto antes e venham a favorecer o reconhecimento e a garantia de seus direitos em todas as regiões do planeta, revelando o que ainda não sabemos - mas precisamos, mais do que nunca, conhecer.

"A verdadeira imagem do passado perpassa, veloz. O passado só se deixa fixar, como imagem que relampeja irreversivelmente, no momento em que é reconhecido" (BENJAMIN, 1994).

\section{Referências bibliográficas}

ALMEIDA, Carina Santos de. Tempo, memória e narrativa kaingang no oeste catarinense: a tradição Kaingang e a proteção tutelar no contexto da transformação da paisagem na Terra Indígena Xapecó. Tese (Doutorado em História) - Programa de PósGraduação em História, Universidade Federal de Santa Catarina - UFSC. Florianópolis: UFSC, 2015. 
ARZE QUINTANILLA, Oscar. El impacto social de las represas hidroeléctricas en los grupos étnicos americanos. In: SEMINÁRIO EFECTOS SOCIALES DE LAS GRANDES REPRESAS DE AMÉRICA LATINA. 1983, Buenos Aires. Anais... Buenos Aires. p. 201-215.

ASPELIN, Paul e SANTOS, Silvio Coelho dos. Uruguay Basin Poject: Damming the Indians os Southem Brazil. In: ARC/Antropology Resource Center Newslette, Boston, Massachussetes, v. 3, n. 4, 1979.

ASPELIN, Paul; SANTOS, Silvio Coelho dos. Indians Areas Threatened by Hydroeletric Projects in Brazil. Copenhagen: IWGIA, Document n. 44, 1981.

ASPELIN, Paul; SANTOS, Silvio Coelho dos. Áreas Indígenas Ameaçadas por projetos hidrelétricos no Brasil. Anais do Museu de Antropologia, n. 12; 15. Florianópolis: Editora da UFSC, 1982.

ASSOCIAÇÃO DE EX-PRESOS POLÍTICOS ANTIFASCISTAS (AEPPA). A política de genocídio contra os índios do Brasil. 16 de março de 1974, Arquivo Nacional.

AVISC - Acervo Virtual de Silvio Coelho dos Santos. Disponível em: $<$ https://avisc.wordpress.com/>. Acesso em 30 maio 2018.

BANIWA, Gersem dos Santos Luciano. O Índio Brasileiro: o que você precisa saber sobre os povos indígenas no Brasil de hoje. Brasília: Ministério da Educação, Secretaria de Educação Continuada, Alfabetização e Diversidade; LACED/Museu Nacional, 2006.

BARTOLOMÉ, Leopoldo J. Relocalización Masiva de poblacion: objetivos para los programas de accion social. Programa de relocalización y accion social. Pras. Dirección de Coordinación. Entidad Binacional Yacyretá. Nov. 1980. 35p. (mimeo).

Aspectos sociales de la relocalizacion de la poblacion afectada por la construccion de grandes represas. In: SEMINÁRIO EFECTOS SOCIALES DE LAS GRANDES REPRESAS DE AMÉRICA LATINA. 1983, Buenos Aires. Anais... Buenos Aires.

BARTOLOMÉ, Miguel A. Procesos interculturales: antropología política del pluralismo cultural en America Latina. México: Siglo XXI Editores, 2006.

BECKER, Bertha K. Repensando a questão ambiental no Brasil a partir da geopolítica. In: LEAL, M.C. (Org.). Saúde, ambiente e desenvolvimento: uma análise interdisciplinar. São Paulo: HUCITEC/ABRASCO, 1992. p. 127-152.

BENJAMIN, Walter. Magia e técnica, arte e política. São Paulo: Brasiliense, 1994 [1985].

BLOEMER, Neusa M. Sens; NACKE, Aneliese. Revisitando o Toldo Chimbangue. Rev. de Antropologia, São Paulo, v. 39, n. 2, p. 199-218, 1996. 
BRIGHENTI, Clóvis. A. O movimento indígena no oeste catarinense e sua relação com a Igreja Católica na Diocese de Chapecó/SC nas décadas de 1970 e 1980. 2012. Tese (Doutorado em História) - Programa de Pós-Graduação em História, Universidade Federal de Santa Catarina - UFSC. Florianópolis: UFSC, [2012].

BRIGHENTI, Clóvis A.; WITTMANN, Luisa T. Indigenismo e movimento indígena Xokleng, Kaingang e Guarani. In: BRANCHER, Ana; LOHN, Reinaldo L. (Orgs.). Histórias na ditadura: Santa Catarina: 1964 - 1985. Florianópolis: Ed. da UFSC, 2014. p. $109-138$.

CADAL - Centro Antropológico de Documentación de América Latina. Documentos: n 0. México: ago. 1976.

CADAL - Centro Antropológico de Documentación de América Latina. Documentos n 1. México: jan. 1977.

CADAL - Centro Antropológico de Documentación de América Latina. Simposio Barbados II. Movimientos de Liberación Indigena en América Latina. Bridgetown Barbados: 18-28 jul. 1977.

CADAL - Centro Antropológico de Documentación de América Latina. Documentos: n 3. México: set. 1977.

CADAL - Centro Antropológico de Documentación de América Latina. Documentos: n 4. México: dez. 1977.

CADAL - Centro Antropológico de Documentación de América Latina. Documentos: n 5. México: mar. 1978.

CANALI, Gilberto Valente. A definição do Projeto Uruguai. In: SANTOS, S.C.; REIS, M. J. (Org.). Memória do Setor Elétrico na Região Sul. Florianópolis: UFSC, 2002. p. 111-129.

CARDOSO DE OLIVEIRA, Roberto. A crise do indigenismo. Campinas: Editora da UNICAMP, 1988.

CARVALHO, Edgar de Assis. Avá Guarani do Ocoí-Jacutinga: parecer antropológico. São Paulo: CIMI-Sul/CJPPR/ANAÍ-PR, 1981.

CASTRO, E. V.; ANDRADE, Lucia M. M. Hidrelétricas do Xingu: O Estado contra as Sociedades Indígenas. In: SANTOS, Leynad A. O.; ANDRADE, Lúcia M. M. (Org.). Hidrelétricas do Xingu e os Povos Indígenas. Comissão Pró-Índio de São Paulo, 1988. p. 7-24.

CASTRO, Paulo Afonso de Souza. Angelo Cretã e a retomada das Terras Indígenas no Sul do Brasil. 2011. 159 f. Dissertação (Mestrado em Antropologia Social) - 
Programa de Pós-Graduação em Antropologia Social, Universidade Federal do Paraná UFPR. Curitiba: UFPR, [2011].

CATUllo, María R. A Antropologia e as represas hidroelétricas do Brasil. Universidade de Brasília: Cadernos da América Latina, n. 1, 1996.

CEDI/PETI/MNRJ. Terras Indígenas no Brasil. São Paulo: CEDI; Rio de Janeiro: PETI/MNRJ, 1987.

CENTRO DE MEMÓRIA VIRTUAL. Relatório da Comissão Figueiredo, 1968. Disponível em <http://www.docvirt.com/docreader.net/docmulti.aspx?bib=ListaArmMemCRV_T_DO C\&pesq=>. Acesso em 23 abr. 2018.

CNBB. Y-Juca-Pirama: o índio: aquele que deve morrer. Documento de urgência de Bispos e Missionários. 25 dez. 1973. Disponível em: <http://urubui.blogspot.com.br/2012/02/y-juca-pirama.html >. Acesso em 23 abr. 2018.

COMISSÃO DA VERDADE DO ESTADO DE SÃO PAULO. Violações aos direitos dos povos indígenas, 2015. Disponível em: <http://verdadeaberta.org/relatorio/tomoi/parte-ii-cap2.html >. Acesso em 22 abr. 2018.

COMIÇÃO NACIONAL DA VERDADE. Violações dos Direitos Humanos dos Povos Indígenas, $2014 . \quad$ Disponível em: <http://200.144.182.130/cesta/images/stories/CAPITULO_INDIGENA_Pages_from_R elatorio_Final_CNV_Volume_II.pdf>. Acesso em 19 out. 2017.

CORREIA, Jáder Figueiredo (Org.). Relatório da Comissão de Inquérito incumbida de apurar as irregularidades do SPI. Rio de Janeiro, 1967.

D'ANGELIS, Wilmar. Toldo Chimbangue: história e luta Kaingang em Santa Catarina. Xanxerê: CIIMI-Sul, 1984.

DAVIS, Shelton. Vítimas do milagre: o desenvolvimento e os índios do Brasil. Rio de Janeiro: Zahar, 1978.

DAVIS, Shelton H.; MANGET, Patrick. Povos primitivos e ideologias civilizadas no Brasil. In: JUNQUEIRA, Carmen; CARVALHO, Edgard de A. (Org.). Antropologia e Indigenismo na América Latina. São Paulo: Cortez, 1981. p. 37-66.

ELETROSUL/CNEC. Bacia hidrográfica do Rio Uruguai - Estudo de Inventário Hidroenergético. Florianópolis, Eletrosul - Centrais Elétricas do Sul do Brasil S.A, e Consórcio Nacional de Engenheiros Consultores S.A, 1979.

FÜRBRINGER, Nádia Philippsen. Coleções Etnográficas: objetos, fotografias e registros de campo: novas articulações e ressignificações. 2013. 129 f. Dissertação 
(Mestrado em Antropologia Social) - Programa de Pós-Graduação em Antropologia Social, Universidade Federal de Santa Catarina - UFSC. Florianópolis: UFSC, [2013].

HELM, Cecília M. V. A UH Salto Santiago e os Índios da Área Mangueirinha, PR. In: . (Org.). A implantação de usinas hidrelétricas e os indígenas no Sul do Brasil.

Relatório. Curitiba: PIAB/IAP/GTZ, 1996. p. 45-68.

ILHA - Revista de Antropologia, Florianópolis, v. 10, n. 1, 2008.

IORIS, Edviges Marta. Uma floresta de disputas: conflitos sobre espaços, recursos e identidades sociais na Amazônia. Florianópolis: UFSC, 2014.

LAGO, André Aranha Corrêa do. Estocolmo, Rio, Joanesburgo: o Brasil e as três conferências ambientais das Nações Unidas. Brasília: Fundação Alexandre de Gusmão, 2006.

LEITE, Ilka Boaventura (Org.). Laudos Periciais Antropológicos em debate. Florianópolis: NUER/ABA, 2005.

LEME MACHADO, Paulo Affonso. Direito Ambiental Brasileiro. São Paulo: Imprenta Malheiros, 2013.

MAGALHÃES, Sonia. O desencantamento da beira: reflexões sobre a transferência compulsória provocada pela usina hidrelétrica de Tucurui. In:.MAGALHÃES, Sonia et al (Org.). Energia na Amazônia. Belém: Museu Paranaense Emílio Goeldoi/Universidade Federal do Pará/Associação das Univ. Amazônicas, 1996.

MARTINS-COSTA, A. L. B. Uma retirada insólita: a representação camponesa sobre a formação do Lago de Sobradinho. Dissertação (Mestrado em Antropologia Social). Museu Nacional, Universidade Federal do Rio de Janeiro. Rio de Janeiro, 1989.

NACKE, Aneliese et. al. Os Kaingang no oeste catarinense: tradição e atualidade. Chapecó: Argos, 2007.

NACKE, Aneliese; WEBER, Cátia. A hidrelétrica de Itaipu e os Guarani do OcoíJacutinga. In: HELM, Cecília M. V. (Org.). A implantação de usinas hidrelétricas e os indígenas no Sul do Brasil. Relatório. Curitiba: PIAB/IAP/GTZ, 1996.

NACKE, Anelise; BLOEMER; Neusa M. S.; LANGE, Ana. Laudo Antropológico Toldo Chimbangue. Florianópolis: Universidade Federal de Santa Catarina; Brasília: Fundação Nacional do Índio, 1984.

NACKE, Aneliese Nacke; BLOEMER, Neusa M. et. al. Os Kaingang no oeste catarinense: tradição e atualidade. Chapecó: Argos, 2007.

NUTI, Miriam R. Integração Energética na América do Sul: Escalas, Planejamento e Conflitos. 2006. 304 f. Tese (Doutorado em Planejamento Urbano e Regional) Programa de Pós-Graduação em Planejamento Urbano e Regional, Universidade Federal 
do Rio de Janeiro - UFRJ. Rio de Janeiro: UFRJ, [2006].

OLIVEIRA, João Pacheco. Pluralizando tradições etnográficas: sobre um certo mal-estar na antropologia. In: LANGDON, Esther Jean; GARNELO, Luísa (Org.). Saúde dos povos indígenas: reflexões sobre antropologia participativa. Rio de Janeiro: ContraCapa, 2004. p. 9-34.

REIS, Maria José. Estado, Hidrelétricas e Sociedade: implicações político-ideológicas. CONGRESSO BRASILEIRO DE ECONOMIA E SOCIOLOGIA RURAL, 29, Campinas, 1991. Anais... Brasília, 1991.

Espaços vividos, migração compulsória, identidade: os camponeses do Alto Uruguai e a Hidrelétrica de Itá. 1998. 253 f. Tese (Doutorado em Ciências Sociais) Programa de Doutorado em Ciências Sociais, Universidade Estadual de Campinas UNICAMP. Campinas: UNICAMP, [1998].

RIBEIRO, Darcy. Culturas e línguas indígenas do Brasil. Rio de Janeiro: Centro de Pesquisas Educacionais, 1957.

RIBEIRO, Gustavo Lins. Cuanto más grande mejor? Proyectos de gran escala: una forma de producción vinculada a la expansión de sistemas económicos. Desarrollo Económico, Buenos Aires, v. 27, n. 105, p. 3-27, abr.-jun. 1987.

SANTOS, Silvio Coelho dos Santos. Os Grupos Jê em Santa Catarina. Florianópolis: Faculdade de Filosofia, Ciências e Letras da UFSC, 1963.

A integração do índio na Sociedade Regional. A fundação dos postos indígenas em Santa Catarina. Florianópolis: EdUFSC, 1970.

O Homem Índio sobrevivente do Sul. Porto Alegre: Editora Garatuja, 1978.

Indigenismo e Expansão Capitalista: faces da agonia Kaingang. Florianópolis: UFSC, 1979 (Concurso de Professor Titular em Antropologia).

Índios e brancos no Sul do Brasil: a dramática experiência dos Xokleng. Florianópolis: EDEME, 1973; Movimento/INL, 1987

A barragem de Ibirama e as populações atingidas na área: documento Denúncia. Boletim de Ciências Sociais, Florianópolis, n. 51/52, Depto de Ciencias Sociais, UFSC, 1991.

Metodologia para o estudo de projetos de desenvolvimento e suas implicações políticas: o caso das hidrelétricas. In: ARANTES, A., et al. Desenvolvimento e direitos humanos: a responsabilidade do antropólogo. Campinas: Ed. UNICAMP, 1992.

Os Índios Xokleng: Memória Visual. Florianópolis: Editora da UFSC/UNIVALI, 1997. 
(Org.). Memória da Antropologia no Sul do Brasil. Florianópolis: Ed. Da UFSC: ABA, 2006.

SANTOS, Silvio Coelho dos. A geração hídrica da eletricidade no sul do Brasil e seus impactos sociais. In: Ensaios Oportunos. Florianópolis: Academia Catarinense de Letras e Nova Letra, 2007.

Notas sobre Ética e Ciência. In: LEITE, Ilka B. (Org.). Estética e Ética na antropologia. Florianópolis: Programa de Pós-Graduação em Antropologia Social da UFSC, CNPQ, 1998.

SANTOS, Leynad A. O.; ANDRADE, Lúcia M. M. (Org.). Hidrelétricas do Xingu e os Povos Indígenas. Comissão Pró-Índio de São Paulo, 1988.

SANTOS, S. C.; ASPELIN, P. Áreas Indígenas Ameaçadas por projetos hidrelétricos no Brasil. Anais do Museu de Antropologia, n. 12, 15, Florianópolis: Editora da UFSC, $1979 ; 1982$.

SANTOS, Silvio Coelho dos et al. Informe sobre os índios Avá-Guarani, ocupantes da AI Ocoí (PR) relocalizados pela UH Binacional Itaipu. Florianópolis: UFSC, 1994 (mimeo.).

SCHERER-WARREN, Ilse; REIS, Maria José. As barragens do Uruguai: dinâmica de um movimento social. Boletim de Ciências Sociais, Florianópolis, n. 42, 1986.

O movimento dos atingidos pelas Barragens do rio Uruguai: unidade e diversidade. Cadernos do CEAS, Salvador, n. 120, p. 21-34, 1989.

SIGAUD, Lygia. Efeitos Sociais de Grandes Projetos Hidrelétricos: as barragens de Sobradinho e Machadinho. Comunicação do Programa de Pós-Graduação do Programa Antropologia Social do Museu Nacional, Rio de Janeiro, v. 9, 1986.

Implicações sociais da política do setor elétrico. In: SANTOS, L.; ANDRADE, L. As hidrelétricas do Xingu e os povos Indígenas. São Paulo: Comissão Pró-Índio, 1988.

SILVA, Elis do Nascimento. Entre aqueles que incomodam: a práxis antropológica na relação entre hidrelétricas e povos indígenas no sul do Brasil. 2016. 238 f. Dissertação (Mestrado em Antropologia Social) - Programa de Pós-Graduação em Antropologia Social, Universidade Federal de Santa Catarina - UFSC. Florianópolis: UFSC, 2016. Disponível em: $<$ https://repositorio.ufsc.br/bitstream/handle/123456789/175854/345676.pdf?sequence= $1>$.

SILVA, Thayse Jacques. Da Aculturação à Fricção: o início da trajetória acadêmica de Silvio Coelho dos Santos e a emergência da etnologia indígena no Sul do Brasil. 2015. 79 f. Trabalho de Conclusão de Curso (Graduação em Ciências Sociais) - Centro de 
Filosofia e Ciências Humanas, Universidade Federal de Santa Catarina - UFSC. Florianópolis: UFSC, 2015.

SOUZA, José Otávio Catafesto de. Diagnóstico Ambiental do Meio Sócio-Econômico. In: ELETROSUL. Parecer antropológico em subsídio à elaboração do EIA/RIMA. Usina Hidrelétrica de Machadinho, 1997.

TERRA DOS ÍNDIOS. Direção e roteiro: Zelito Viana. Documentário (107min). Brasil, 1979. Disponível em: 〈https://www.youtube.com/watch?v=zeeTx6kQ19s >. Acesso em 19 abr. 2018.

UFSC/FAPEU/ELETROSUL. Projeto Uruguai: os Barramentos e os Índios. Relatório de Pesquisa. Florianópolis, 1978.

Projeto Uruguai: Consequências da construção da Barragem Machadinho para os índios do PI Ligeiro (RS). Relatório de Pesquisa. Florianópolis, 1980.

UFSC/FAPEU/NEPI. Estudo Etnográfico da Usina Hidrelétrica Machadinho. Relatório de Pesquisa apresentado à GERASUL. Florianópolis, dez. 1998.

UFSC/FINEP. A implantação das barragens na bacia do Rio Uruguai e suas implicações sociais: a Barragem de Machadinho e os Índios do PI Ligeiro (RS). Relatório de Pesquisa apresentado à FINEP. Florianópolis, dez. 1988.

VIANNA, Aurélio. Hidrelétricas e Meio Ambiente: informações básicas sobre o Ambientalismo Oficial e o Setor Elétrico no Brasil. Rio de Janeiro: CEDI - Centro Ecumênico de Documentação e Informação (Documento 3), jul. 1989.

Recebido em: 31/05/2018 * Aprovado em: 13/12/2018 * Publicado em: 29/12/2018 